\title{
Bir Değer Yargısı Olarak 'Vakar' ve 'Kibir' Bağlamında Güray Süngü’nün 'Kibir’ Adlı Öyküsünün Göstergebilimsel Çözümlemesi
}

\author{
As Elements of Value Judgement 'Solemnity and Arrogance'; The Contextual \\ Semiotic Analysis of Güray Süngü's Story 'Kibir' (Arrogance)
}

\author{
Prof. Dr. M. Hilmi UÇAN ${ }^{1}$
}

\begin{abstract}
Özet
Göstergebilim, anlatı çözümlemelerinde çözümleme araçlarını açıklayan, kendi yöntemini ortaya koyan bir çözümleme önerisidir. Klasik öykülerin göstergebilimsel çözümlemeleri belli bir yöntem içinde abartısız, övgüden ve yergiden uzak bir şekilde yapılabilir. Ne var ki çağımızda anlatı teknikleri çok değişmiştir. Kimi anlatıların öykü mü, günlük mü olduğu bile tartış1lır duruma gelmiştir. Sözgelimi Cahit Zarifoğlu'nun Yaşamak adlı anlatıları için günlük denilebileceği gibi deneme de denilebilir. Bu anlatılarda şiir de vardır. Güray Süngü’nün Vicdan Sızlar adlı kitabında yer alan öyküler de kendini kolay ele veren klasik öyküler değildir. Bu öykülerde çizgisel bir anlatı yoktur. Öykülerdeki zaman ne çizgisel ne dairesel bir şekille açıklanabilir. Zaman kullanımı çok farklıdır. İronik bir dille zaman kavramı askıya alınır. Yeni evlenen bir kişinin 1 yıl içinde 2 kızı olur; ertesi yıl kızını evlendirir; bir çocuk babasının ölümünden 6 yıl sonra doğar... Evvel Ahir Batın Zahir'deki Kokik 100 yll sevgilisini bekler. Yine ironik bir dille bürokrasi, aile, toplum eleştirilir. Bu kitaptaki öyküler okuyucuya daha çok Derin Düzey'de bir anlam üretme firsatı vermektedir. Bu yazıda bir tür hastalık olarak kabul edilebilecek 'kibir' ve bir değer olarak 'vakar' kavramı açıklanacaktır. Bu çerçevede Güray Süngü’nün adını andığımız kitabında yer alan Kibir adlı öyküsünün göstergebilimsel bir çözümlemesi yapılacaktır.
\end{abstract}

Anahtar Sözcükler: Göstergebilim, anlatı, kibir, Güray Süngü

\begin{abstract}
Semiotics is somewhat an analysis proposal which suggests means of text analysis. It has a peculiar methodology to avail in practicing any analysis on narratives. The semiotic analysis of the classical stories can be applied in a modest form without yielding to any extreme ends of bitter criticism and praise. Literally speaking, there are now narratives which cannot be agreed upon as to whether they are stories or diaries. Cahit Zarifoğlu's narratives titled 'Yaşamak' (rendering life) can be interpreted as either diary or an essay. These narratives embraces poems as well. In Güray Süngü's work, Vicdan Sizlar (Mind Suffers) The stories are not typical classical ones that can release respective forms. These stories do not bear a linear narration. Time in stories can be depicted in neither linear nor circular forms. Use of Time, concept is quite a different issue. The concept of time is somewhat is elusive in an ironic language. A newly-wed person has two daughters in a year; her daughter gets married just the following year; a child is born into the world six years after his father death The Kokik character in the story 'Evvel Ahir, Batın Zahir' (first, last, in and out) looks forward to seeing his/her sweetheart for a hundred years. The concept of bureaucracy and family, society are all under criticism in an ironic language. In this book readers are allowed to produce meaning making
\end{abstract}

${ }^{1}$ Afyon Kocatepe Üniversitesi, Eğitim Fakültesi, ucan@aku.edu.tr, Orcid ID: orcid.org/ 0000-0001-7370-172X 
rather at deep level. In this study 'arrogance', somewhat a disorder and as a value judgement 'solemnity' will be dealt with. Within this frame, Günay Süngü's story 'arrogance' will be studied in terms of semiotic analysis.

Key Words: semiotics, narration, arrogance, Güray Süngü

\section{Giriş}

Sözcüklerin kökenbilimsel anlamlarını bilmek, hissetmek, düşüncenin yaslandığı en önemli dayanak, en önemli ve sağlam duvardır. Sözcüklerin duygu değeri bilinirse, insan daha iyi düşünebilir, daha iyi 'felsefe' yapabilir. İnsan sözcüklerle düşünür. Sonuçta felsefe, sözcükler üzerinde düşünmektir. Gösterilen olarak kafamızda var olmayan bir nesne, bir varlık hakkında düşünce üretme, anlamlandırma olanağı yoktur. Özellikle, gündelik yaşamımızda yer alan soyut kavramlar üzerinde düşünmek ayrı bir çalışmayı gerektirir.

'Vakar' sözcüğünün anlamları arasında 'ağırbaşlılık, deneyim sahibi olmanın verdiği heybet, saygınlık, yumuşaklık...' anlamları var. Vakar sahibi olmak, kendi konumunun gereğini yapmak, yerine getirmek demektir. Vakar sahibi insan 'büyük'tür, ama somut olarak, sözlük anlamıyla 'büyük' anlamına gelen kibir onda yoktur; kibirli değildir.

Kibir sözcüğü ise 'büyüklük, irilik, ululuk anlamlarının yanında aynı kökten bir başka anlamı 'büyük günah' (kebair) anlamını da içerir. 'Aşırı olmak', 'kendini büyük görmek' anlamları da var. 'Ekabir'dendir sözü, Türkçede ironik bir şekilde 'kendini büyük görür' anlamında da kullanılır.

Hayat paradokslarla doludur. Denge sağlanamazsa, insan ya ifratta ya da tefritte gezinir durur ve hakikati gözden kaçırır, kendini tanıyamaz. 'Iffrat' kavramında aşırılık vardır. Sözgelimi 'havuzu taşıncaya kadar doldurmak' bu fille (افر ط ) ifade edilir. 'Tefrit' ise bir şeyi 'aczinden dolayı mahvetmek, kaybetmek' demektir. İfratta bir fazlalık, 'tefrit'te bir noksanlık, eksiklik, kusur, 'bilerek terk etmek' vardır; ortalamanın çok altında kalma anlamı vardır. Kutsal kitapta şöyle buyurulur: "Eyvah! Allah yanında yaptı̆̆ım eksikliklerden dolayı hasretime bak! Doğrusu ben eğlenenlerden idim" (Yazır, 1979: 4132). Bir başka ayette de aynı fiil 'noksanlık, kusur' anlamında kullanılmıştır: "Onlar vazifelerinde noksanlık yapmazlar (Yazır, 1979: 1945). Vakar sahibi olan kişi olabildiğince kusurdan, noksanlıktan, eksiklik ve fazlalık gibi aşırılıklardan, çelişkilerden uzaktır; konumunun gereğini yapar.

Mensubiyet, mesuliyeti beraberinde getirir. Mensup olmak, mesul olmak demektir. Bir insan, İslam'a veya insani bir ideolojiye mensup ise sorumluluğu da vardır; gereğini yapmak durumundadır. Gereğini yaparken, üzülebilir, yenilebilir, kazanabilir. Güray Süngü, bu bağlamda, yenen ve yenileni farklı anlamlandırıyor. Kaybeden ve sürekli yenilenin, aslında kazanan ve yenen kişiler olabileceğini düşünüyor: "İki kişi aynı kapıya doğru yürürken, birisi daha önce o kapıdan geçmek için omuzunu kullanırsa ve diğeri bu düşkünlüğe muhatap olmamak için gönül kırıklığıyla bir saniyeliğine durursa kazanan, kapıdan ilk geçendir der insanlar. İnsanlar bilmiyorlar" (Süngü, Söyleşi: 31.12.2017). Yenilgi gibi görünen onurlu duruşlar vardır; aslında kazananlar böyle bir duruş sergileyenlerdir; vakarlı, onurlu bir duruşa sahip olanlardır. 'Kibir' değil 'vakar' sahibi olan, başka bir deyişle bulunduğu konumun, mensubiyetinin gereğini yapan insan huzurludur. 
Çağımız insanının 'iç'i hastadır. İçeride hastalıklar vardır. İnsanımız, dışarı ile daha çok ilgileniyor. Ne var ki Yaratıcı insanların 'dış'larına, kalıplarına bakmıyor; 'iç'lerine, kalplerine bakıyor. İnsanlık da burada yatıyor olsa gerek. Çocuk veya yaşlı, sanatçı veya değil, insan için 'iç' önemlidir. Gülten Dayığlu Cambaz Parası adlı öyküsünde 'iç rahatlığı ne güzelmiş anneciğim' der. Güray Süngü, öykülerinde bir 'kahraman', bir 'tip' yaratmaya çalışmıyor. Öykülerinde silik kişiler vardır; büyük, 'ne güçlü oyuncu' dedirten kişiler yoktur. Daha çok 'iç'ini gözleyen, 'iç' hastalıklarını görmeye, bulmaya çalışan karakterler var. Süngü, abartma olmadan gerçeğimsi olanı yakalamak düşüncesindedir. Büyük konuşmak istemiyor. Yazısı 'ak', dili güzel. 'Vicdan' sözcüğü de soyut bir kavram. Bu kavram üzerinde de düşünmek gerekiyor. Güray Süngü'nün 17 öyküsünü içeren kitabın adı da bu sözcüğü içeriyor: Vicdan Sizlar.

Vicdan Sızlar adlı kitapta 17 öykü yer alıyor: Vicdan Sızlar, Açılım, Hasarla Beslenen, Unutursam..., Lan, Cana Kıymık, Evvel Ahir Batın Zahir, Küle Dön..., Mahalleden Sesler, Dil Yarası, Maalesef Yasemin Çok Güzeldi, Alışılmadık Bir Mülteci Hikâyesi, Kibir, Yă̆macılar, Mahallede..., Kasaba, Dünyanın En Orta Yeri.

Bu öykülerden Kibir adlı öykü, insanın 'iç’ini ortaya koyan ironik bir öykü. Süngü, bu öyküde okuyucuyu bir özeleştiriye götürüyor, belki kendisi bir özeleştiri yapıyor. Süngü, yazarken 'havalanmamayı' öneriyor. Havalananların "tavana çarpıp yere düşmelerini tavsiye" (Süngü, Söyleşi: 2017) ediyor. Öykülerinde İnsanı zahirde mutlu, kendi içinde, 'vicdan'ında mutsuz eden 'iç' hastalıklarını doğal bir dille, iç monologlar şeklinde dile getiriyor.

\section{Anlatı Düzeyi}

Kibir adlı öykü klasik bir anlatının sınırlarını aşan bir öyküdür. Bu nedenle öyküyü sınırları belli bir şekilde kesitlere ayırmak kolay değildir. Diğer öyküler için de aynı durum söz konusudur. Bunun nedeni de şudur: Güray Süngü'nün öykülerinde kronolojik bir zaman kullanımı ve olay örgüsü yoktur. Tam tersine zaman kullanımı akıl dışıdır. Süngü ve onun öyküleri sadece 'zaman' kullanımıyla bile diğer öykücülerden/öykülerden ayrılır. Bu öyküde eyleyenler var, ama 'oyuncu'dan söz etmek zor. Başka bir deyişle yaşayan, hayatın içinde var olan, ama etiyle kemiğiyle, canlı, kanlı duruşuyla belleklerde kalan bir kişi yok. Öykülerde hasta, cansız, sıradan insanlar var.

Göstergebilimsel bir çözümleme yapılacak olsa, ne Anlatı Düzeyi'nde ne de Söylem Düzeyi'nde, öyküyle ilgili söylenecek çok fazla söz yok. Sözgelimi okuyucu, 'öyküde Özne kim?' 'Özne'nin Nesne'si nedir?', 'Yardım ediciler kim?' veya 'Engelleyiciler kimler?' sorusunu yanıtlamakta zorluk çekiyor. Öykünün bir başlangıç durumu, bir sonuç durumu yok. Bir eyleyenler şeması çıkarılmak istendiğinde okuyucu zorlanıyor. Öyle ki bir anlatı grameri oluşturmak adına öyküde 'ne?', 'nerede?', 'ne zaman?', 'niçin?' soruları sorulsa, bu soruların yanıtı yok. Öykünün tamamı göz önünde bulundurulduğunda Özne'nin nesnesi bile açıkça belirtilmiyor. Amaçsız, rasgele, ilkesiz, sadece haz ve çıkarı için yaşayan birçok çağdaş insan gibidir Özne. Okuyucu, 'Özne ne yapmak istiyor?’ sorusunu da yanıtlayamıyor.

Her anlatıda en az 2, en çok 6 eyleyen vardır. Bu öyküde Gönderici, Özne, Nesne, Yardım Edici üzerinden bir eyleyenler şeması ortaya konulabilir. Yüzeysel Düzey'de değil, Derin Düzey'de söylenebilecek çok söz var. Öyle ki Derin Düzey'de birçok cümlenin 
üzerinde çalış1labilir, düşünülebilir, her cümle ayrı ayrı yorumlanabilir. Sözcüklerin duygu değeri düşünülse, yeni sözler söylenebilecek, farklı yorumlar yapılabilecek bir anlatı söz konusu. Başka bir deyişle Güray Süngü 'ben yazdım, okuyucu düşünsün' diyor, yorum yapmak okuyucuya ait. Kibir adlı öykü de kısa, ama çarpıcı bir öykü. Öyküde abartı yok, derin bir ironi var.

\section{Başlık ve Kapak}

R. Barthes, "başlık aperitiftir" (Barthes, Sémiotique du Titre: 2018) iştah açıcıdır der. Kapak da başlık da okuyucuyu okumaya iteleyen ya da okumaktan vazgeçiren önemli biçimsel özelliklerdir. Nice kitaplar vardır ki kapağı ve başlı̆̆ı ile kendine bir piyasa bulur.

Kitabın adı Vicdan Sizlar. 'Vicdan' sözcüğünün kökeninde 'bulmak' anlamına gelen 've-ce-de' fiili vardır. 'Vicdan, bu fiilin mastarıdır. Vicdan 'iç' ile ilgilidir. Gizlediğimiz, içimizden geçirdiğimiz nice duygular vardır ki çirkindir. Bu duyguları 'vicdan'ımızla kovarız. Kötüyü iyiden, çirkini güzelden, haramı helalden aslında bu kavramla, 'iç'imizle ayırırız. Hatta değerimizi, kıymetimizi, kimse bilmese de biz 'iç'imizle değerimizi biliriz. Türkçede değil ama Arapçada kalple ilgili, 'kalbî fiiller' vardır: 'Bilmek', 'zannetmek', 'bulmak', 'görmek' bu fillerdendir. Bu fiiller 'iç' ile, 'kalp' ile ilgilidir. 'Ve-ce-de' fiili ( وجد ) de 'kalp' ile ilgili fiillerdendir. Bu fiiller aynı zamanda farklı bağlamlarda 'anlamak', 'zannetmek', 'şüphe etmek', 'sorumlu tutmak', 'hatırlamak'... anlamlarına geliyor. Başka bir deyişle bu filler kalbi ilgilendirir, insanın içinden geçenleri dışa vurur. 'Seni iyi bir insan bilirdim'; 'kitabım yırtılmış, ben seni bilirim'; 'bunu senden bilirim'; 'doğrusu sizi bilemedim', 'seni üzüntülü gördüm'... Bu tür cümleler bizim içimizi, sevgimizi veya nefretimizi, duygularımızı dışa vurur:

'Okçuluğun, hat sanatı için faydalı olduğunu gördüm' demek 'okçuluğun faydalı olduğunu anladım, kalbimden buna inandım' demektir. 'Gördüm ki bu hayat kolay değil' demek, 'anladım, kalbimden inandım ki hayat zor' anlamındadır. Kutsal Kitap'ta "O senin yetim olduğunu bilip de seni barındırmadı mı? Seni, çocukluğunda gaaib olmuş bulup da yolunu doğrultmadı mı? Seni, bir fakir olduğunu bilip de, zenginleştirmedi mi?" (Çantay, 1969: 1191-1192) denilir. 'Vicdan', bulmak anlamındadır. Vicdan hakikatin, doğru olanın arayarak bulunduğu yerin adıdır. 'Vicdan sahibi olmak', kalbiyle doğru olanı bulmak ve teslim olmak demektir. Bu tür farklı anlamlarının yanında bu 'kalple ilgili fiiller', Arapçada farklı yazım kurallarına uymak zorundadırlar.

Kitabın adı okuyucuyu kendi içine döndürüyor; okuyucudan düşünmesini bekliyor; vicdanın sızlaması gerek dedirtiyor. 'Vicdan Sızlar' deniliyor başlıkta. Ama neden? Okuyucu meraklanıyor. Bu sorunun yanıtı da öyküler okunduktan sonra ortaya çıkacaktır.

Kapakta bir kayığın üzerinde Özgürlük Heykeli, Eyfel Kulesi ve Pisa Kulesi var. Bunlar çağdaş dünyanın simgeleridir. Tevhitten, tek Tanrı inancından uzak uygarlıklarda simgeleştirilen, resme ve yapıya dönüştürülen bir yükseklik, büyüklük duygusu vardır. İnsanlıktaki yükseklik duygusunun, kibrin, kendini büyük görmenin simgeleri, sembolleri bu tür göstergelerdir. Firavun da kendini büyük gördüğü için ehramları yapmıştır. Yükseklere çıkıp 'ben sizin Rabbinizim” demiştir. Eyfel Kulesi, sanayi devrimiyle gelen kibrin, yükseklik duygusunun demir yığını şeklinde dile getirilişidir. Bu kule aklın, demirin, tekniğin her şeyi çözebileceğinin simgesi ve iddiasıdır. Özgürlük heykeli de öyledir: 
Amerika en büyüktür; tacın üzerinde 7 kıtanın 7 denizin simgesi olarak 7 çubuk vardır. Heykelin elinde ise bir meşale vardır. Bu meşale, başka bir deyişle Amerika bütün dünyayı aydınlatacaktır.

Ne var ki kitabın kapağındaki kayık kâğıttandır. Bu büyük yapılar kayığa ağır gelmektedir. Okuyucu kulelerin büyüklüğünü, kayığın küçüklüğünü hemen görüyor, hissediyor; bu kuleler her an kayığı yırtabilir, suya batırabilir. Bu büyüklügü bu kayık, bu beden çekmez' diyor okuyucu. Kendini büyük görmek, kibirlenmek insanı batırır... Kitabın adı ve kapağı da bu açıdan baktığımızda anlamlıdır. İnsan bu dünyada gurbettedir. Gurbette olana hüzün yakışır. Zira o, hasreti ta yüreğinin derinliklerinde duyar. Hüzün sahibi olmak, dertli olmak, derdi olmak insan olmanın belki de ilk şartlarındandır. Gurbetteki insan kendini büyük görmez, haddini bilir. Kitabın adı okuyucuda 'gör, içinden anla, bil, hakikati bul, bu bedene bu kadar büyüklük sığmaz, kalbini çalıştır, vicdanınla düşün, vicdanın sızlasın...' anlamlarını çağrıştırıyor.

Öyküye epigraf olarak konulan cümleler, 'öykünün başkişisi' olduğu söylenen Sadenur'un sözleridir. Bu sözler, başarı odaklı bir yaşamdan alınacak hazzı vurguluyor; 'ben' duygusunu yüceltiyor: "Yaptım, söyledim, not aldım, takla attım, büyüdüm." Öykünün 'başkişisi' olarak bildirilen Özne (Sadenur Kocaoğlu) 'resim' yapıyor, 'şarkı' söylüyor, 'misafirlerin önünde takla' atıyor; herkes gülüyor, o da büyüyor. Anlatıcı kendini dev aynasında görüyor; aynaya sığmıyor. Hatta aynada kendini görebilmek için biraz eğiliyor, 'kambur' bakıyor kendini görmek için. Bir de kendisi hakkında şöyle bir kanıya sahiptir: "O kadar iri ve güzeldim ki!" Dahası kendisinin 'dört kişi kadar', dört insan büyüklüğünde olduğunu düşünüyor cisim olarak, madde olarak. Yürüyüşü de gururludur, kasıntılıdır, 'lambır lumbur' yürür. Kişisel gelişim kitaplarını çok okuyan çağdaş bir insan gibi. Öyküde var olan ironiye ayrı bir tat katan iki güzel sıfat: 'İri ve güzel'. Aslında, 'küçük güzel'dir. Öyküde ironik bir dille yanlış olan vurgulanıyor. Sonuçta Özne yere düşüyor ve kalkamıyor. Okuyucu 'insanda ne kadar da büyük bir 'ben' var; Allah, 'insanı bu 'ben' ile sinava aliyor' diyor.

Anlatıda eyleyenler şemasında sadece Özne ve onun nesnesinden söz edilebilir: Özne herkesi küçümser, başkasını küçük görmekten hoşlanır; yaşamdan anladığı başkasını küçük, kendini büyük görmektir. Başka bir deyişle nesnesi kendi iç dünyasındadır: "Galiba bu kitabı benim gibi harika birisi yazmamıştı"; "harikayım ben" der. "Dev gibi bir cüssesi" olduğunu düşünür. Arkadaşı için "acıdım ona" der. "Sırıtır". Olay örgüsü diyebileceğimiz bir 'örgü' şayet denilebilirse- sadece öznenin iç monologlarıdır. Anlatıda şöyle bir Eyleyenler şeması kurulabilir:

Tablo 1. Eyleyenler Şeması.

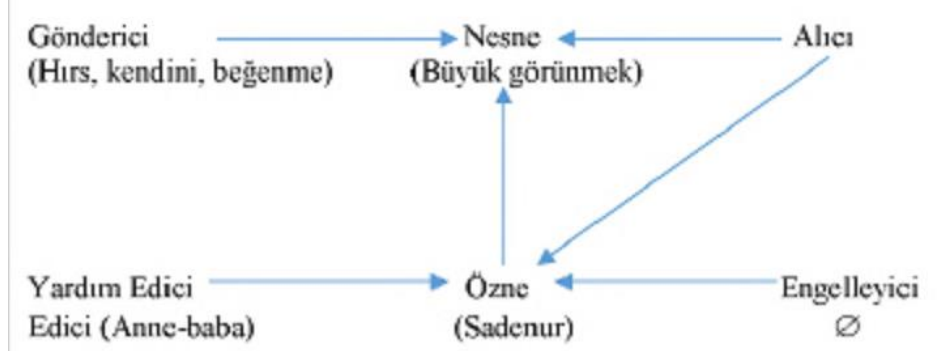


Öyküde bir Başlangıç Durumu, bir Sonuç Durumu söz konusu değil. Eyletim aşaması olarak sadece Özne'nin 'iç dünyası', 'hırs'1, 'kendini beğenmesi' var. Edinç aşamasında Özne'ye gerekli gücü sağlayan, ona yardım eden anne ve baba, aile ve toplum var. Edim aşamasında ise Özne nesnesine kavuşuyor. Ne var ki küçük bir 'ittirme' ile yıkılıyor ve ayağa kalkamıyor. Yaptırım aşamasında Özne, Nesne'sinden ayrıdır: Kibirli olmanın cezasını çeker.

\section{Söylem Düzeyi}

Göstergebilimin temel olarak kabul ettiği bir kural vardır: Anlam, karşıtlıklardan, zitlıklardan doğar. Anlatı Düzeyi'nde ortaya konulan Eyleyenler Şeması'nda sadece eyleyenler gün yüzüne çıkarılırken, Söylem Düzeyi'nde dikkatler "birbirine karşıt olan figüratif özellikler üzerinde yoğunlaştırılır" (Everaert-Desmedt, 1988: 65). Metindeki 'oyuncular' ortaya konulur. Bu işlem yapılırken karşıtlıklardan, zıtlıklardan hareket edilir. Bundan sonra da varsa imgeler, bakış açısı ve izleksel roller üzerinde durulur.

Kibir adlı öyküde Yüksek/Alçak; Büyük/Küçük; İyi/Kötü zıtlıkları ilk dikkati çeken zıtlıklardır. Söylem Düzeyi'nde bir 'kahraman' oyuncu yoktur. Öykü kişisi olarak Nurbanu var, Celal var, Sadenur var, Başak var. Bir de öykünün sonunda Anlatıcıyı ittirip yere düşüren 'minicik' cüssesiyle Hulusi var. Ama hepsi de silik kişiler. İzleksel rolleri yok. Bu oyuncular etiyle kemiğiyle, öfkesiyle canlı, civelek, cesur... değildirler. Bu kişiler öykü içinde yok gibiler, ama varlar. Çünkü okuyucuyu gülümsetiyorlar; öyküyü okurken gizlice gülüyor, gülümsüyor okuyucu. Annenin ve babanın söylediklerine gülümsüyor. Baba'nın oğlu için söyledikleri şunlar: 'Akı1lı oğlum benim; tatlı oğlum benim; çalışkan, yakışıklı.. oğlum benim'. Kusur, yanlış yok oğulda. Anne de Baba'dan geri kalmıyor oğlunu övmekte: 'Güzel oğlum gelmiiiiş’ der eve gelince. Koşar boynuna sarılır oğlunun. Öyküde baştan sona ironik bir söylem biçimi var. Öyküde annenin, babanın bir adı yok; kilosuna, göz ve saç rengine vb. karakteristik çizgilere hiç girilmiyor.

Annesi, oğlunun başını okşar hep. Babası uzaktan bakar. Her ikisi de oğulları hakkında sadece övgü cümleleri kurar. Oğul da büyüklerinin kendisi için kullandığı sıfatları (büyük, yakışıklı, çalışkan, tatlı, akıllı...) alır kabul eder, başka bir deyişle kendini bu sıfatlarla özdeşleştirir, öyle olduğuna inanır. Kırılmaz, sarsılmaz bir benlik, bir kibir oluşur anlaticida.

Yetişkinlerden bir de öğretmen var. Bu öğretmenin kişiliğinde eğitim sistemi de ironik bir şekilde masaya yatırılıyor. Öğretmenin anlattıkları da mizah konusu ediliyor: Öğretmen Amazon nehrinin en uzun nehir olduğunu söylüyor. Bu bilgi aktarımında çağın hastalığ1 olan nicelik söz konusudur; nitelik değil, nicelik önemli, önceliklidir. Nehrin niteliğinden değil niceliğinden söz ediliyor; insanı hayrette bırakan, şaşırtan, Yaratıcı'yı düşündüren 'debi'sinden, güzelliğinden söz edilmiyor. İnsana eğitim içinde, Amazon nehrinin uzunluğunu, Himalaya dağının yüksekliğini ezberlemek yetiyor. Sinavlarda da bu sorulacaktır. Anlatıc1 da 'en uzun nehir' tamlamasını, 'en uzun zehir' olarak anliyor. Öğretmen ‘öyle değildir' diyor. Öğrenci 'kibirli’ bir karaktere sahiptir, şöyle yanttlyor: 'Ben öyle anladıysam artık öyledir.' Öğretmen çok kızıyor, ama bir şey diyemiyor, söyleyemiyor, 'kürsüsüne oturup ağlıyor.' Öğretmenin saygınlığı, kendisine sayg1 duyulan 'öğretmen' 
nerede? Bu yanıtı veren öğrenci ise kibirlidir, bir kere daha kendisiyle gurur duyuyor. Çünkü herkes ona bakmaktadır. Herkes, bir şeyleri göstermek, dikkat çekmek, ben buradayım demek, şöhrete ulaşmak istiyor. Öğrenci de dikkat çekmek istiyor. Yapılan her eylemin sonucunda insan, kendisini daha büyük gösterecek bir durumu gözetiyor. Alçakgönüllülük, kendini tanımak değil kibir ve çıkar öne alınıyor.

\section{Bakış Açısı}

Öyküler okuyucuya akıl vermiyor; akıl vermeye çalışmıyor. Öyküde ironik bir söylem biçimiyle okuyucu düşündürülüyor. Toplum içinden sıradan bir kişinin tavrı olarak bir benlik ve bir kişilik betimlemesi yapılıyor. Öykülerde kendi içini ve dışını gözlemleyen, kendini büyük gören, büyük olduğuna inandırılmış bir anlatıcı, bir iç gözlem söz konusudur. Sınırlı bir bakış açısı vardır. Anlatıcı, kendi dünyasından bildiklerini, gözlediklerini bildiği kadar, anladığ 1 kadar, sezebildiği kadar dile getiriyor. Öykülerde çoğu zaman geçmiş zaman kipi kullanılmaktadır. Bu seçim de öyküye bir kesinlik kazandırıyor.

Halk ozanlarının söyleşisinde olduğu gibi bir biçem de var: 'Dedim başkana bu ne? Dedi sana ne?' Birbirini yanlış anlayan, Karagöz/Hacivat diyaloglarını da anımsatan bir söylem biçimi söz konusudur. 'Bisikletin nerde dedi bana. Sana ne ki dedim ben de ona. Kinle baktı bana.' 'Az gittim uz gittim, dereyi kim içmiş, tepeyi kim ezmiş, düz gittim' diyen masalımsı bir atmosfer de var. Bu özellikler ve bu söylem biçimi öyküdeki ironiyi güçlendiriyor.

\section{5. İzleksel Roller}

Anlatıdaki oyuncuların hemen hemen hepsi de siliktir. Yalnızca Sadenur için yoğun bir sıfat kullanımından söz edilebilir. Kullanılan sıfatlar da fizyolojik özellikleri açıklayan sıfatlar değil anlatıcının iç dünyasını, karakterini ortaya koyan sıfatlar.

Anlatıdaki oyuncuların izleksel rollerini şöyle bir tabloda gösterebiliriz:

Tablo 2. İzleksel roller

\begin{tabular}{|l|l|}
\hline Kişiler & İzleksel Roller \\
\hline $\begin{array}{l}\text { Anlatıcı } \\
\text { Sadenur) }\end{array}$ & $\begin{array}{l}\text { Akıllı, tatlı, çalışkan, yakışıklı, kafası biraz büyük, parmakları büyük, sesi } \\
\text { gür, alaycı, iri, güzel, dev gibi, kusursuz, harika, muhteşem, kibirli, hep } \\
\text { doğruları söylediğine inanan, merhametli olduğunu düşünen, tepeden bakan, } \\
\text { kindar }\end{array}$ \\
\hline Anne & Şefkatli, oğlunu çok öven. \\
\hline Baba & Oğlunu seven, öven, zengin olmayan. \\
\hline Nurbanu & Küçük, aptal, silik. \\
\hline Celal & Aptal, silik. \\
\hline Hulusi & Salak, silik. \\
\hline Başak & Silik. \\
\hline Öğretmen & Zayıf, aciz. \\
\hline
\end{tabular}

Öyküde uzam olarak ev, evin salonu, okul, sınıf, bakkal, mahalle, 'dışarı', 'içeri' gibi açı ve kapalı uzamlar var. 


\section{Derin Düzey}

Öykü, Derin Düzey'de kibirli insanlarla alay ediyor. İnsanın bir de yapamadıklarını, başkasının kendisinden daha çok şey bilebileceğini, daha iyi, çalışkan, akıllı, güzel... olabileceğini düşünmesi gerekmez mi? Okuyucu bunu hissediyor. Bir de, tersinden şunu düşünüyor: Anlatıcı kendisini 'büyük', 'iri’, ‘dev gibi’ görüyordu. Büyük olan, Kadîr olan, Yaratıcı olan Allah’tır, insan aciz bir varlıktır; düşündüğü her şeyi gerçekleştiremez... Sadenur da Hulusi'nin küçük bir itişiyle düşüyor ve bir daha kalkamıyor.

Anlatıcı annesini, babasını, Nurbanu'yu, bakkalı... herkesi küçümser. Baba eve girer selam verir, anlatıcı selamı almak istemez, 'lütfen' karşılık verir. Annesi de biraz 'aptal'dır, arkadaşı Celal ise daha da 'aptal' bir insandır; anlatıcı sadece acır ona. Sınıf arkadaşı Başak'a da acıyarak bakar. Okulda ise 'herkes aptaldır'. Yanına Hulusi gelir. Onun için de şöyle diyor: 'Ben bu salak çocukla dalga geçmeye bayılırdım.' Hulusi'nin cüssesi de miniciktir, kendisi ise 'dev' gibidir. Hulusi ondan korkar, o ise sırıtır, bıyık altından ona güler. Babası da pek akıllı değildir. Sadenur, okuduğu kitabı da beğenmez, kendini beğenir sadece. 'Galiba bu kitabı benim kadar harika birisi yazmamış' diye düşünür. Nurbanu da 'o kadar küçüktür ki!’ Anne küçük, baba küçük, ögretmen küçük, yani yetişkinler küçük, herkes küçüktür. Herkese, gelen geçene tepeden bakan bir oğul var öyküde. Dahası, bu oğul kendisinin iyi olduğuna, 'kötü' olmadığına inanıyor: 'Allah'tan kötü biri değilim' der. Bu yeterli değil: 'Harika', 'muhteşem', 'merhametli' olduğuna inanıyor. İronik olan da şu: Herkes ona hayrandır; büyük olan odur. Okuyucunun öfkesi zaman zaman zirveye çıkıyor; 'insan vakar sahibi olmalı, ama kibirli, kendini beğenmiş biri olmamalı’ diyor.

'Sadenur' anlatıcının adı mı? Seda Nur şeklinde yaygın olarak kullanılan isimler var, ama Sadenur adında ne kadar insan vardır bilinmez. Böyle bir isim de boşa seçilmemiş. Bu isim de güldürüyor okuyucuyu. Annesi anlatıcıya sesleniyor: 'Sadenur aç kapıyı yavrum baban geldi.' Anlatıcı kızıyor: 'Ne saçmaydı, inanamadım, ben mi açacaktım kapıyı'. Sadenur, kapıyı açmaya gitmez. Anne gider kapıyı açar 'bir elinde bıçak, diğerinde sivri biber'. İnsanımız, toplum birçok kavramı karıştırır, değiştirir, istediği şekle dönüştürür, bireysel doğrular, bireysel helaller ve haramlar ortaya koyar.

Bu anlatıyı Derin Düzey'de göstergebilimsel dörtgen üzerinde şöyle özetleyebiliriz:

Tablo 3. Göstergebilimsel dörtgen

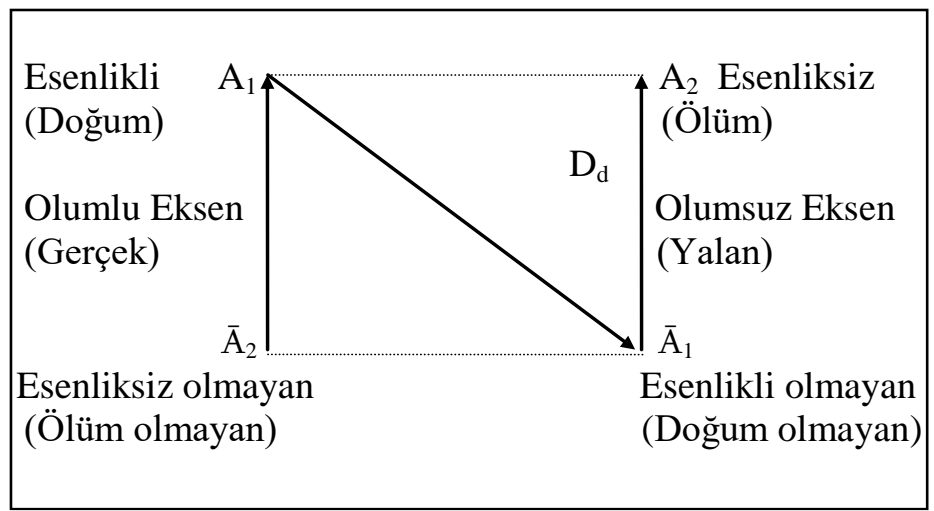


Doğum ve ölüm insanın içinde ‘ömür' tükettiği bir gerçeklik çizgisidir. İnsan doğar, büyür, ölür. Hiçbir canlı bundan kurtulamaz. Doğum, aynı zamanda esenlikli bir durumdur. Ölüm ise üzer, esenliksiz bir durumdur. Öykü, doğum noktasından $\left(\mathrm{A}_{1}\right)$ başlar. Anlatıcı, başlangıç durumunda esenlikli bir durumdadır. Bir ailesi, annesi, babası, bir evi vardır. Ne var ki annesi ve babasından aldığı yeterli, iyi bir terbiye yoktur, şımartılır. Sürekli övgülere boğulur. Her zaman başı okşanır. 'Akıllı'dır, 'harika'dır, 'muhteşem'dir, 'çalışkan'dır, 'yakışıklı'dır, 'iri'dir, 'tatlı'dır... Böyle davranılınca anlatıcı da kendisi hakkında bir karar verir: 'Mademki bu kadar çokum, niye kendimi az hissedeyim' der. Kendini 'büyük' görür; kibir onun en önemli karakteri hâline gelir.

Bu kötü gen kalınlaşarak, güçlenerek büyür. Herkesi küçümsemeye başlar. Herkes 'aptal'dır, sadece kendisi akıllıdır. Öyle ki anne ve babası dâhil herkes 'küçük'tür. Nesneler bile onun gözüne küçük görünür. Ev de küçüktür; evi de beğenmez, daha büyük bir ev ister. Bu durum, esenlikli olmayan bir durumdur. 'Doğum olmayan', esenlikli olmayan bir duruma $\left(\overline{\mathrm{A}}_{1}\right)$ geçer. Arkadaşının 'cüssesi' küçücüktür, kendisi ise 'dev' gibidir; her şeye layık olan kendisidir. 'Salak' der arkadaşı için. Anlatıcı güler, sırıtır. Küçümsendiğini anlayan arkadaş1 'minik eliyle' onu hafifçe itiverir. 'dengesiz' yakalanır, düşer. Şimdi geldiği nokta 'Ölüm' noktası $\left(\mathrm{A}_{2}\right)$ dır. Kalkıp onu 'sinek gibi 'ezmek ister. Ama kalkamaz. Y1llar geçse de bir türlü doğrulup ayağa kalkamayacaktır. Anlatıcı her şeyi yapmış ama bir şey yapamamış birisidir. Her şeyi yaşadığından dolayı, hep övüldüğü için esenlikli bir duruma ulaşamamıştır. Vakar sahibi olamamıştır; kibir onu yıkar, yere düşürür. Bu eksen, aslında bir 'yalan'ın yaşandığı eksendir: Büyük olmadığı hâlde kendini büyük gören bir karakter söz konusudur.

\section{Sonuç}

Yaşam içinde insan üzülür, sevinir, nefes alır, boğulur. Yazmak, düşünmek bir bakıma teskin olmak, sükûn bulmak, rahatlamak demektir. Süngü de öykünün kendini teskin ettiğini, yatıştırdığını düşünüyor. Bu yatışmanın meyveleri de daha çok Hece, Hece Öykü dergilerinde verilmiştir.

Güray Süngü kendisine acı veren, kendi deyiş̧iyle 'ağrıtan' şeyler hakkında cümle kurar, ama akıl vermek için cümle kurmaz. Bu 'ağrı', bu dile getiriş "olsa olsa bir sezgi hâlidir" (Süngü, Söyleşi: 2015), sezer, hisseder, dile getirir. Bütün öykülerinde yorumu okuyucuya bırakır. Ona göre, bakarak değil, görerek, yaşayarak öykü yazılır: "İçimizi delen şeyden çıkar hikâye, bakıp da gördüğümüz şeyden değil’’(Süngü, Söyleşi: 2015).

Yazınsal çözümlemelerde dikkate alınması gereken 'metin'dir, dildir. R.Barthes bir diğer uç noktada 'yazar'ı öldürür, yazarı aradan çıkararak metne, dile öncelik vermeyi önerir. Yazar Tatili (L'écrivain en Vacances) (Barthes, 1957: 30-33) adlı yazısında metne, yazınsal değere dikkat çekmek adına, yazarın bir tür kral, bir tür üstün insan, bir tür XIV.Louis olmaması gerektiğini söyler. Yazarın reklamından hoşlanmaz. Ne var ki insanın doğasında böyle bir iç hastalığı vardır: Görünmek ve göstermek ister. Reklamlarla bu durum abartılır. Yazarın giydiği mavi pijamadan, yediği peynirden, sevdiği lavanta çiçeği balından söz etmek yazarı biraz daha yıldızlaştırır; onu sadece hayranlıkla izlenen bir konuma yerleştirir ve biraz daha bu topraklardan uzaklaştırır. Böyle bir tavır yazınsal ürünleri de kutsallaştırır. 
Güray Süngü için yazı, yaşamdan ayrı düşünülemeyecek bir etkinliğin adıdır. Şöyle diyor: "Yazmak hayatın dışında, başarmak için uğraşılan bir şey değil, hayatın tam da kendisidir. (...) Dergiciler çok konuşmamalı. Dikkati eserden çekecek her şey sanata, edebiyata ihanet. (...) Eser kendisi bir çığlık değil mi zaten?” (Süngü, Söyleşi: 2017). İnsan kendi elleriyle kendisini çirkinleştirir ya da güzelleştirir. Bir söyleşisinde şöyle diyor: "İnsanın eline bir firça verirler, insan onunla ya kendini boyar çirkinleştirir ya bir duvarı boyar güzelleştirir" (Süngü, Söyleşi: 2015).

Öyküde gizli gizli, ironik bir söylem biçimiyle aile, okul ve toplum eleştirilir. İfrat; taşıncaya kadar havuzu su ile doldurmaktır; tefrit ise havuza yeterince su koymamaktır. Her ikisi de bir dengesizliktir. Kişisel olgunluk için 'ifrat' ve 'tefrit'ten uzak bir dengenin sağlanması gerekir. Kibir, insana acziyetini, zayıflıklarını unutturur; insanlığından çıkarır, havuzu taşırır, insanı öldürür. Özgüven kaybı da bunun tersidir. İnsan haddini, şerefini, gücünü, aczini bilmelidir. Bu denge kibir veya aşağılık duygusu ile sağlanamaz; ancak vakar ile sağlanır.

Bir sanatçı 'ben'i vardır. Sanatçının çoğu zaman beğenisi yüksektir; kolay beğenmez, özeleştiriden uzaklaşabilir. Bir sanatçı ödül sahibi olabilir ama 'havalı' olamaz. Güray Süngü de 'havalı' olmamayı, 'havalanmamayı', kibirlenmemeyi önerir; eksikleri olabileceğini düşünür. Böyle bir bakış yazıda ve sanatta önemli bir incelik olsa gerektir.

$\mathrm{Bu}$ öykülerdeki 'oyuncular hüzünlü ve sıra dışıdır. Süngü, kendisi de 'üzgün' olduğunu söylüyor. Kitaplarındaki kişiler için "birbirimize benziyoruz" (Süngü, Söyleşi: 2017) diyor. Kibir adlı öykü aslında ironik bir hicivdir, sanatçının bir özeleştiri öyküsüdür: Öyküde anlatıcı şöyle diyor: "Galiba bu kitabı benim gibi harika birisi yazmamış."

Okuyucu ya da yazar, sanatçı, kısacası insan kendini hesaba çekmeli, bir özeleştiri yapmalıdır. Yabancılar tarafından, "sınırları cetvelle çizilmiş bir ülkede" vakar sahibi olmak edinilmesi gereken bir 'değer'dir. Kibir lise düzeyinde, karakter ve değerler eğitiminde de okutulabilecek bir öyküdür.

\section{Kaynakça}

Barthes, R. (1957). Mythologies, Paris: Ed. du Seuil.

Barthes, $\quad$ R.(2018)

(Aktaran.R.MARTY), http://perso.numericable.fr/robert.marty/semiotique/s081.htm 14.02.2018.

Çantay, H. B. (1969). Kur'ân-ı Hakîm ve Meâl-i Kerîm, İstanbul: Ahmed Said Matbaası.

Everaert-Desmedt, N. (1988). Sémiotique du Récit, Bruxelles: De Boeck.

Süngü, G. (2017). http://www.izdiham.com/guray-sungu-ile-roportaj-yaptik/ (Erişim tarihi: 31.12.2017)

Süngü, G. (2015). http://www.guraysungu.com/index.php/2015/03/01/oyku-kalbimi-teskinediyor. (Erişim tarihi: 31.12 .2017 )

Süngü, G. (2016). Vicdan Sizlar, İstanbul: İz Yay.

Yazır, H. (Elmal111). (1979). Hak Dini Kur'an Dili, (3.Cilt: En'am Suresi) İstanbul: Eser Neşriyat.

Yazır, H. (Elmal111). (1979), Hak Dini Kur'an Dili, (6.Cilt: Zümer Suresi) İstanbul: Eser Neşriyat. 